\title{
Savena, Volvona, Ravona: The Origins of Bologna
}

\author{
Giampietro Fabbri* \\ Eubios Study Center, Bologna Italy / Alma Mater Studiorum, University of Bologna, Italy
}

Submission: October 30, 2018; Published: November 09, 2018

*Corresponding author: Giampietro Fabbri, Eubios Study Centre, Alma Mater Studiorum, University of Bologna, Italy

\begin{abstract}
In this study the origins of the city of Bologna are investigated by analysing the geographical names of its area and comparing them to similar toponyms and ethnonyms in Italy and in Eurasia. In this way, traces of the ancient peoples that migrated to the Italian peninsula are detected. In particular, the role of Proto-Scythians, Proto-Umbrians, and Proto-Etruscans in populating the Padanian Valley and Bologna area are analysed. To this aim, archaeological finds in Bologna territory are taken into consideration. The names of the earl peoples that inhabitated the urban area of Bologna are then reconstructed and the peoples themselves are put in relationship with the phases of the ancient city.
\end{abstract}

Keywords: Bologna; Felsina; Etruscans; Umbrians ; Sabines ; Migrations

\section{Introduction}

It is widely known that, before the Roman domination and the Gallic infiltration, in the teritory of current Bologna an Etruscan city was located. Etruscans called this city by the name Vélzena (where the second vowel actually was a sound intermediate between Lat. e and i, corresponding to $\eta$ Greek letter), translated into Lat. Félsina. Since Etruscans frequently used in writing to omit internal unstressed vowels [1], the city name was usually written as Velzna. However Velzqna / Velzna was not the only name used by the Etruscan people nor the oldest one referred to the place. In fact, even the current name Bologna has an Etruscan origin. Moreover, other peoples living in the area before and beside Etruscans left to us testimonies of the name by which the place was indicated at their time.

According to a recent diffusion theory [2,3], Etruscans were a confederations of tribes descending from two disticnt peoples: ${ }^{*}$ Thyr $G^{w}$ aunas and ${ }^{*} G^{w}$ aulgwaunas. The latter descended from Proto-Scythians and spoke a Proto-Indo-European language. Like their ancestors, they lived mainly on cattle breeding. *Thyrg ${ }^{w}$ aunas descended from tribes living on the border (cf. Gr. $\theta \dot{v} \rho \alpha$, door) between Proto-Scythians and mongoloid morphology peoples. They resulted from the crossing of theese populations and spoke Proto-Altaic dialects. Being a border people, they where subjected to commercial and cultural exchanges, developing the attitude to the commerce and reaching an higher cultural level. The tribes descending from ${ }^{*}$ Thyrg ${ }^{w}$ aunas that settled in Italy, specialised in commercing with the other Italic people, absorbing their cultural influence. They lernt the script, probably by Greeks [4], and developed an alphabet adapted to their own language. The Italic descendants of ${ }^{*} G^{w}$ aulg ${ }^{w}$ aunas probably acquired the script already elaborated by those of ${ }^{*}$ Thyrg ${ }^{w}$ aunas and use it in an ideographical way.
That means that they wrote Velzna but they read this sign as the name by which they called the city in their own language. This is the reason for which in the Etruscan inscriptions we do not find alphabetical translitterations of this name. However, it survived with minor deformations until nowadays in the oral tradition. Moreover, we can reconstruct it, as well as other toponyms still used in the Etruscan age to indicate the place of current Bologna, by analysing ancient and modern geographical names in the territories occupied by Etruscans and their ancestors.

\section{Proto-Scythians and Proto-Hiberians}

Proto-Scythians were originally known as the "cow breeder people". The names reconstructed for their tribes [2] can in fact be derived from the term * swag $^{w}$ aus, to which the meaning of "own cow", "bred cow", or "herd of cows" can be attributed. The most common derivations of this term are *Swagwau-tas, ${ }^{*}$ Swag ${ }^{w} a u-n a s$, and *Swagwau-las, from which for example the historical Gr. forms $\Sigma \kappa v \dot{\theta} \theta \iota$ [5] and - $\sigma \alpha \gamma \varepsilon \dot{\tau} \tau \iota \iota$ (as in $M \alpha \sigma-\sigma \alpha \gamma \varepsilon \dot{\tau} \tau \iota \iota$ [6]), the Ass. Askuzai [7] and the Hebr. Askenaz [8,9] (from the ablative *Swagwaun-at, "from the country of cow breeders") can in turn be derived.

Proto-Scythians as well as Proto-Hiberians descended from *Suparsthas [2], a caucasoid morphology population that concentrated on the mountains of Armenia probably as a consequence of a flood on Mesopotamia after the melting of glaciers of the last glaciation. From the name of *Suparsthas those of the historical peoples of Subarus, Hurrians, Parthians, Kurds, Hattians, Persians, Arsi, Ari, Asi can be obtained through common phonetic changes [2].

While the ancestors of Proto-Hiberians (*Suparas / *Subaras / Hubaras) expanded northward through Caucasus, those of 
Proto-Scythians moved eastward through the Iranian highlands and northward into the grasslands of southern Russia, where they miggled with a minority concentration of mongoloid peoples. As a consequences of this crossing, the morphology of Proto-Scythians differentiated from that of Proto-Hiberians. The former were for example less dolichocephalic than the latter, having a flatter forehead and different orbital curvature.

In the last half of the III millennium BC Proto-Scythians started to move eastward from current Kazakhstan, forcing ProtoHiberians to penetrate Europe or flow back through Caucasus. At the beginning of II millennium BC the border line between Proto-Hiberians and Proto-Scythians was approximatively located from Anatolia to current Poland. In this border area some hybrid peoples generated from *Swagwaunas and ${ }^{*} H u b a r a s$ (> ${ }^{*} G^{w}$ aunas Hubras $>G^{w}$ aumbras) and from *Swagwaulas and ${ }^{*}$ Hubaras ( $>{ }^{*} G^{w}$ aulas Hubras $>{ }^{*} G^{w}$ aulubras): $G^{w}$ aumbras rose inside the Únětice culture [10], in a cultural exchange area where the main ancient commercial routes between Europe and Asia (along Rhine, Elbe, Vistula, Danube, and Boristhenes rivers) crossed; ${ }^{*} G^{w}$ aulubras developed in the southern part of the border zone being the ancestor of the Anatolian Chalybes and the Italic Calabri. Chalybes were considered the inventors of metallurgy, while the italic descendants of $G^{w}$ aumbras started by the Adriatic coast a metal processing tradition which continued until nowadays and probably passed their name to the Latin word faber $\left(<{ }^{*}\right.$ gau'ber $<{ }^{*} g^{w}$ aumbra $)$.

During the great migration of the beginning of the II millennium $\mathrm{BC}$ the borderline was displaced up to the Rhine valley while Proto-Hiberians and the hybrid peoples were pressed to the peripheral areas of Europe. In particular $G^{w}$ aumbras were forced to move to the North Sea and Baltic Sea and to descend on Italy, where they overlapped *Hubaras / *Lubaras (ancestors of Ligurians) previously immigrated. By analysing the names of the historical descendants of $G^{w}$ aumbras (Cimbri, Cambri, Cumbri, Humber, 'Ambrones, 'Umbrians), we can recognise the tendency of this peoples to transform the labiovelar $\mathrm{g}^{\mathrm{w}}$ into unvoiced velar also aspired and muted.

In the historical age the descendants of $G^{w}$ aumbras in Italy, Ambrones and Umbrians, were located in Liguria [11] and around Umbria, respectively. However, between these two regions some geographical names attest the past presence of relatives of these peoples. In particular, we can cite near Bologna the Sambro river and further south the Ombrone river, whose names can be derived from $G^{w}$ aumbras (for the change of $g^{w}$ to s see belove).

Shortly after the arrival of $G^{w}$ aumbras, Proto-Scythians started penetrating the italic peninsula. We can recognise the names of *Swagwautas / ${ }^{*}$ Swagwaunas / ${ }^{*}$ Swagwaulas in the historical names of Sabates, Sabines, and Sabelli, whose ancestors enter Italy from the north, and in those of Sicani and Siculi / Asculi (> Apuli), whose ancestors reached the peninsula through the Otranto strait.
In the historical age Sabates were mainly located by the Ligurian coast and in western Lazio, Sabines in eastern Lazio, and Sabelli further south. However some geographical names demonstrated the past presence of peoples descending from Proto-Scythians also in north-eastern Italy, and, in particular, in the area of Bologna and around. The names of Aposa torrent and Savena river can be in fact derived from *swagwaus (> ${ }^{*}$ Savaus $>$ *Savos $>$ *Abos $>$ Apo-sa) and *Swag"wauna ( ${ }^{*}$ Savaina $>$ Save-na), respectively. The change from Abos to Apos can be explained by noticing that in the Etruscan alphabet the voiced occlusives were missing and substituted by the respective unvoiced ones [12]. However, trace of the voiced labial remains in the diminutive form Avesella. Moreover, the Etruscan change from $b$ to $p$ leads us to find testimonies of peoples relatives of Sabines in EmiliaRomagna in the names of Savio (Lat. Sapis; but the voiced labial survives in current name) river and Spina $\left(<{ }^{*}\right.$ Sabina; with Etruscan omission of the internal unstressed vowel) city, both near "Ravenna Sabinorum oppidum" [13]. Livy mentions a Tribus Sapinia inside the Roman army against Gauls Boii [14].

It is important to notice that $G^{w}$ aumbras spoke a langauge similar to that of ${ }^{*} S w a g^{w} a u n a s$. In the historical age, the descendants of these peoples in Itlay, Umbrians and Sabines, respectively, spoke dialects belonging to the Osco-Umbrian language family. In the endonyms of the descendants of ${ }^{*}$ Swag ${ }^{w}$ aunas in northern and central Italy the labiovelar gw then resulted probably in velar, as in the name of their relative Sigynnae [15], in the Danubian area and France, and of Siculi and Sicani in southern Italy. However, in northern and central Italy we received the names of the descendants of * Swag ${ }^{w}$ aunas through people in whose languages the labiovelar resulted in labial. In particular, in Bologna and its region we received this names through the descendants of ${ }^{*} G^{w}$ aulgwaunas, who changed the labiovelar into $\mathrm{v}$ and later $\mathrm{b}$. Therefore, we received the names Savena and Sabina as well as derived toponyms such Savigno or Savignano and family names such as Savini.

A trace of the Osco-Umbrian result in velar of the labiovelar $\mathrm{g}^{\mathrm{w}}$, can be found in the dialectal name of Reno river, which flows west of Bologna (Figure 1). This river took it name after the descendants of ${ }^{*}$ Thyrg $^{\text {waunas }}$ who settled in current Casalecchio to control the commercial route through Reno and Ombrone valleys. The name Reno is in fact a shorter form of Gr. Tyrrhnnos corresponing to Etr. *Tarchnna (<*Targainas < *Thyrg $\left.{ }^{w} a u n a s\right)$. In Bologna dialect this river is called Raggn (<*Ragghena), in which the voiced velars correspond to the sibilant in the name Rasna (see below).

Moreover, it is important to observe that in the name of ${ }^{*}$ Swag ${ }^{w}$ aunas the most important part is $g^{w} a u$, which indicates the cow breeder nature of the people. Therefore, this syllabe was stressed. In the names of ${ }^{*}$ Thyrg ${ }^{w}$ aunas and ${ }^{*} G^{w}$ aulgwaunas the most important parts are Thyr and $G^{w} a u l$, which distinguish the one people from the other. Therefore, this peoples stressed the first syllabe of their names and tended to do the same on the 
name of their neighbours. In Bologna, where the descendants of *Thyrg ${ }^{w}$ aunas and ${ }^{*} G^{w}$ aulgwaunas were the majority, the accent on the first syllabe (Sàvena) prevailed, while by the Adriatic coast, where they were the minority, the second syllabe remained stressed (Sabìna $>$ Sapìna $>$ Spìna).

\section{The Mixed People}

${ }^{*}$ Thyrg ${ }^{w}$ aunas were originally located, as we said, in Central Asia on the northern border of *Swagwaunas. In the III millennium BC the latter broke into the territory around Volga river, separating the former into two branches: the eastern one was forced towards Mongolia and China, the western one towards Mesopotamia, Anatolia, and Eastern Europe [2]. The former would flow back westward during the great migration of the XIII-XII century BC, caused by the expansion of Mongol and Chinese peoples. ${ }^{*}$ Swag ${ }^{w}$ aunas bordering on ${ }^{*}$ Thyrg ${ }^{w}$ aunas then assumed the name ${ }^{*} G^{w}$ aulgwaunas. In the course of time the two peoples fought each other, interacted and joined into a multilingual confederation of peoples, that in the Aegean area was known as ${ }^{*} M y k g^{w} a u n a s$, the Mixed People.

By analysing the historical names of the peoples descended from ${ }^{*} G^{w}$ aulgwaunas and ${ }^{*}$ Thyrg ${ }^{w}$ aunas we can observe that the internal labiovelar $\mathrm{g}^{\mathrm{w}}$ mainly results in labial or velar in IndoEuropean dialects, in unvoiced velar also aspirated or muted in dialects of Western ${ }^{*}$ Thyrg $^{w}$ aunas, and in dental (d, dh or z) and $\mathrm{s}$ in dialects of Eastern ${ }^{*}$ Thyrg $^{w}$ aunas. Moreover the initial labiovelar $g^{\mathrm{w}}$ results in labial, velar and less frequently in $\mathrm{s}$, while the initial th results in t, s, and ph [3]. From the terms ${ }^{*}$ Gwaulg ${ }^{w}$ aus and ${ }^{*} G^{w}$ aulg ${ }^{w}$ aunas we can then obtain for exampe the historical names Volga, Volcae, Belgae, Caledones, Halizones, while from ${ }^{*}$ Thyrg ${ }^{w}$ auas and ${ }^{*}$ Thyrg ${ }^{w}$ aunas we can derive those of Thraces, Phryges, Arzawa, Tarhun, Perkūnas, Tyrsenoi, Tyrrhenoi, Shardana. Finally, from the terms ${ }^{*} M y k g^{w} a u s$ and *Mykg ${ }^{w}$ aunas we can obtain the names of Mysians / Moesians (Gr.

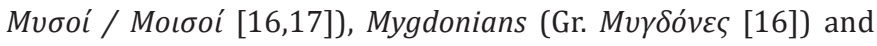
Mycenaeans (Gr. Mvкńvaı [18]). Moreover, we can observe that in the course of time the derivations of the term $g^{w}$ auna lose the original meaning of "related to cow", "group of cows", "refuge for cows" and assume that of "group of cow breeders", "community", "fortified village".

Western *Thyrg ${ }^{w}$ aunas reached Central Europe between the end of the III millennium BC and the beginning of the second one and partecipated to the Únětice culture. They were forced to Italy together with $G^{w}$ aumbras, to whom they had handed their tendency to aspirate the velars. They also reached the Italic peninsula by sea from Anatolia through stopovers on the African coast and the Italian islands. The descendants of Eastern *Thyrg ${ }^{w}$ aunas reached Central Europe at the end of the great migration of XIII-XII century BC, pressing westward descendants of *Swag ${ }^{w}$ autas $\left({ }^{*} S^{w}{ }^{w}\right.$ etas / ${ }^{*} S g^{w} y$ tas later Sveti, Svitti and Itali), Proto-Gaul-Latins, and the descendants of ${ }^{*} G^{w}$ aulgwaunas, all peoples who had settled in the area between Black Sea and Baltic Sea. These peoples entered Italy the one shortly after the other. The last to settled in the peninsula was the Mixed People, i. e. the confederation of the discendants of ${ }^{*} G^{w}$ aulgwaunas and *Thyrg ${ }^{w}$ aunas.

In the historical age the Mixed People was known as Tusci or Etrusci, ethnonyms derived from the alternations of the names of the merchant tribes, who descended, as we said, from ${ }^{*}$ Thyrg ${ }^{w}$ aunas (or Thyrg ${ }^{w}$ aus > Turkas / Tursas > Umbr. Tursko [19] > Lat. Tu'sci / Lat. E-trusci). They were settled mainly by the Thyrrhenic coast from Liguria to Campania, on the border between Tuscany, Lazio, and Umbria and also in the Padanian Valley and by the Adriatic coast from Veneto to Marches. However, by analysing the geographical names we can find testimonies of the Mixed People in the whole northern Italy and we can recognise the presence of descendants of ${ }^{*} G^{w}$ aulgwaunas inside the Etruscan people. In particular, the name Velzna or Velznna can be derived, through the discussed phonetic changes,

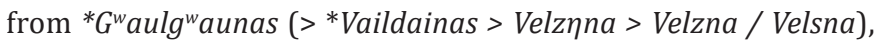
thus appearing to be the name by which the tribes descending from this people were indicated by the other ones. Therefore the toponym Velzna (and later Velsna) indicated a place inhabitated by descendants of ${ }^{*} G^{w}$ aulgwaunas. Beside Bologna, we know the existence of at least one other city which Etruscans called Velzna. It was probably located where is now Orvieto [20] or Bolsena [21] and was called Volsinium o Volsinii by Romans. However, several modern Italian toponyms can be derived from Velzqna, as Bolzano, for example.

It is probable that Velzqna also was the original name of Vallescura torrent, which in the Roman age flowed along the western side of Bononia. According to some authors [22], this torrent originnally flowed aproximatively in correspondence with the western side of the XIV century walls of Bologna and was diverted in the late Etruscan age or later (Figure 1). It is possible that Etruscans just created an eastern branch to bring water inside Velznna or Romans diverted the torrent to protect their city. The current name of the torrent in Italian means "dark valley". However, this name does not corresponds to the torrent location. In fact, Vallescura torrent collected the waters from the northern side of Osservanza hill, where no deep or narrow valley is osservable and the slope of the hill side does not cause shadow in most part of the day during the year. In earl documents (XII century AD) the name of Via Vallescura, the street located at the hill side where the torrent flowed, is attested as Val de Scura \&Vallis Scuris [23]. However, these names should be reformations of the popular voice, which was probably Val Scôra, a reinterpretation of the terms derived through the tradition from Velsena, Volsona, or Valsona, in turn derived from Velzqna. To support this hypothesis, on the watershed between the Vallescura and Ravone basins is now a street called Bellinzona. The name of the street was reformed during the Fascist regime, as occurred to many toponyms (cf. Agrigento / Girgenti). Previously, the street assumed the name "Stradello dei Capuccini" after the Franciscan monastery [24], but the original name, alternately used, could be Belzona $(<$ Velzona $<$ Velznna $)$, 
which sounded as a dialectal corruption and was corrected in Bellinzona by the reformers.

The descendants of *Thyrgwaunas called themselves Tarchuna [25] (< *Targunas < *Thyrg ${ }^{*}$ aunas), Rasna or Rasenna [26] (< * Traznnas < *Tardainas < *Thyrgwaunas), Sarsna (<

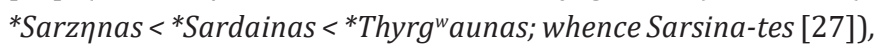
and Phersna (<*Pherzqnas < *Terdainas < *Thyrgwaunas; whence Phersna-las [28]). By considering the Indo-European phonetic changes and the current name of Bologna we can deduce that the descendants of ${ }^{*} G^{w}$ aulg ${ }^{w}$ aunas inside the Etruscan People called themselves Volvona or Volvoni and later Bolboni. Volvona and later Bolvona, Bol'ona, Bol'onia, and Bolbona were the name by which they, and later the Gauls, called their settlements. When Romans founded their colony in 189 BC on the remains of Felsina, by the time destructurised by Gauls, they gave it the name Bononia as an reinterpretation of Gaulish Bolbona. However the name Bolonia survived in the local population and we received it with just a minor change.

By comparing Velsna with Volvona we can deduce that the descendants of ${ }^{*} G^{w}$ aulg ${ }^{w}$ aunas called Rasna or Rasenna by the names Ravona or Ravenna. We can find attestations of this ethnonyms in the territory of Bologna and nearby in the names Ravone and Ravenna. The former indicates a torrent which flows through western Bologna, the latter the city that Rasna probably refounded on the village of that people they called (at least in writing) Sapina or Spina.

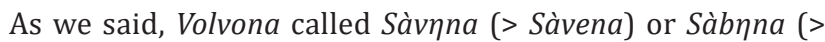
Sabìna) the descendants of *Swag ${ }^{w}$ aunas and Ràvona wrote the name of the latter as Sapina or Spina. Moreover, Savena spoke an Osco-Umbrian dialect, in which probably the labiovelar $\mathrm{g}^{\mathrm{w}}$ had resulted in velar as in Umbrian. Therefore, they called *Kailkana (< ${ }^{*} G^{w}$ aulgwaunas) or ${ }^{*}$ Kai'kana $\left(<{ }^{*} G^{w} a u^{\prime} g^{w}\right.$ aunas $)$ the descendants of ${ }^{*} G^{w}$ aulg ${ }^{w}$ aunas. The latter form contracted in Kaikna, Ceicna, and Caicna, is attested as family name in the area between Bologna, Volterra, and Volsinii [29]. In Bologna the family name Kaikna was particularly diffused. This family probably descended from some Volvona who originally lived where OscoUmbrian speakers were prevalent. Their members subsequently immigrated in the Volvonian urban area and assumed Estruscan individual names showing the Volvonian origin, as in case of Vel Kaikna [30]. From the form ${ }^{*} \mathrm{G}^{\mathrm{w}}$ au'gwaunas also the name of Faenza (Lat. Faventia < ${ }^{*}$ Faezna $<{ }^{*}$ Vaizna $<{ }^{*} G^{w} a u^{\prime}$ gwauna) and Cesena (Lat. Caesena $<{ }^{*}$ Kaizna $<{ }^{*} G^{w} a u^{\prime}$ gwauna) can be derived. As in case of Cesena, several current geographic names derive from a mix of the Volvonian-Savenian or Ravonian-Savenian form. This is for example the case of Calvana mount chain and Calenzano city nord of Florence or Calbano mount by Sarsina.

In the following we call Sàvena, Vòlvona, and Ràvona the descendants of *Swag ${ }^{w}$ aunas, *Gwaulgwaunas, and *Thyrg ${ }_{\text {w }}$ aunas, respectively.

\section{Archaeological Finds}

The archeological finds dating back to the period commonly associated with the Etruscan presence discovered in the territory of Bologna can be classified referring to three phases [31]: formative (IX-VIII century BC), proto-urban (VIII-VI century BC), late-urban (VI-V century BC).

In the formative phase an initial increase can be observed in the concentration of the habitative structures, which were less distantly spaced with respect to the villages of the previous late bronze age. Most of the discovered habitations and cemeteries were located near the river Savena [32], which flowed further west than nowadays (Figure 1).

In the proto-urban phase an additional increase can be observed in the concentration of the habitative structures, which were mostly located inside a limited area between the torrent Aposa and the western limit of the XIV century city, where probably Vallescura torrent or a branch of it originally flowed. Most of the structures of this phase were located along the streets of the current city, beacause they were mainly discovered during municipal works for canalisation and route restructuration, starting from those directed by Antonio Zannoni in the XIX century. Cemeteries were located east of Aposa torrent, west of Ravone torrent, and north of the urban area. The zone near Savena torrent, previously inhabitated, was almost abandoned.

In the proto-urban phase, the habitations still were huts covered in straw as in the previous one. Wall were made of vertical poles joined by filling of clay or straw. The base shape was circular or elliptical. The archaeological finds concerning this huts consist in holes in the ground where poles had been driven and fragments of building materials. The other finds of this phase are objects discovered in the inhabitaded zone and in the cemeteries. In particular, in the western part of the city several bronze objects and fragments have been found. In current San Francesco square, a vase was discovered containing nearly 15000 bronze pices probably destined to be fused [33]. This leads to think that this part of the city was dedicated to the metal processing. Moreove, in the adjacent zone up to Ravone torrent few holes have been found in the ground while cemeteries have been discovered across that torrent. This leads to think that this area could be occupied by less stable structures which left no trace. In cemeteries, tombs became in this phase monumental and decorations assumed orientalising characteristics.

In the late-urban phase the urban characteristics of the city were enhanced. This is few appreciable on the basis of the scarce archaeological finds concernig the habitations. However this can be deduced by observing the development of an area dedicate to the rite and the sacrality in a high ground zone of the city (acropolis) in the middle between Aposa and Ravone torrents. Moreover, this can been understood by reading the inscriptions, mainly found in cemeteries, reporting the names of military and administrative roles which demonstrate a more specialised 
organisation of the city and control of the surrounding territory. The urbanisation of the city can be also appreciated in this phase by observing the development in the communication structures. In particular, the ancient route coonecting the city to the Reno valley was provided with a new cobble pavement and lateral drains, assuming monumental characteristics matched with those of the cemeteries that rose around. The particularity of this phase is therefore the fact that the habitative structures discovered in the city are not appreciably different from those of the previous phases. Tiles, which were a kind of roofing usual at that time in the near settlement by the Reno river (Casalecchio di Reno), have not been found in Bologna area except for the acropolis [34].

In the area surrounding Bologna archaeological finds have been discovered, which date back to the formative fase in Castenaso, Villanova-Ca' dell'Orbo, Ronzano, Casalecchio, to the proto-urban phase in Castenaso, San Lazzaro-Caselle, Casalecchio, to the late-urban phase in Casalecchio [35-37] (Figure 1).

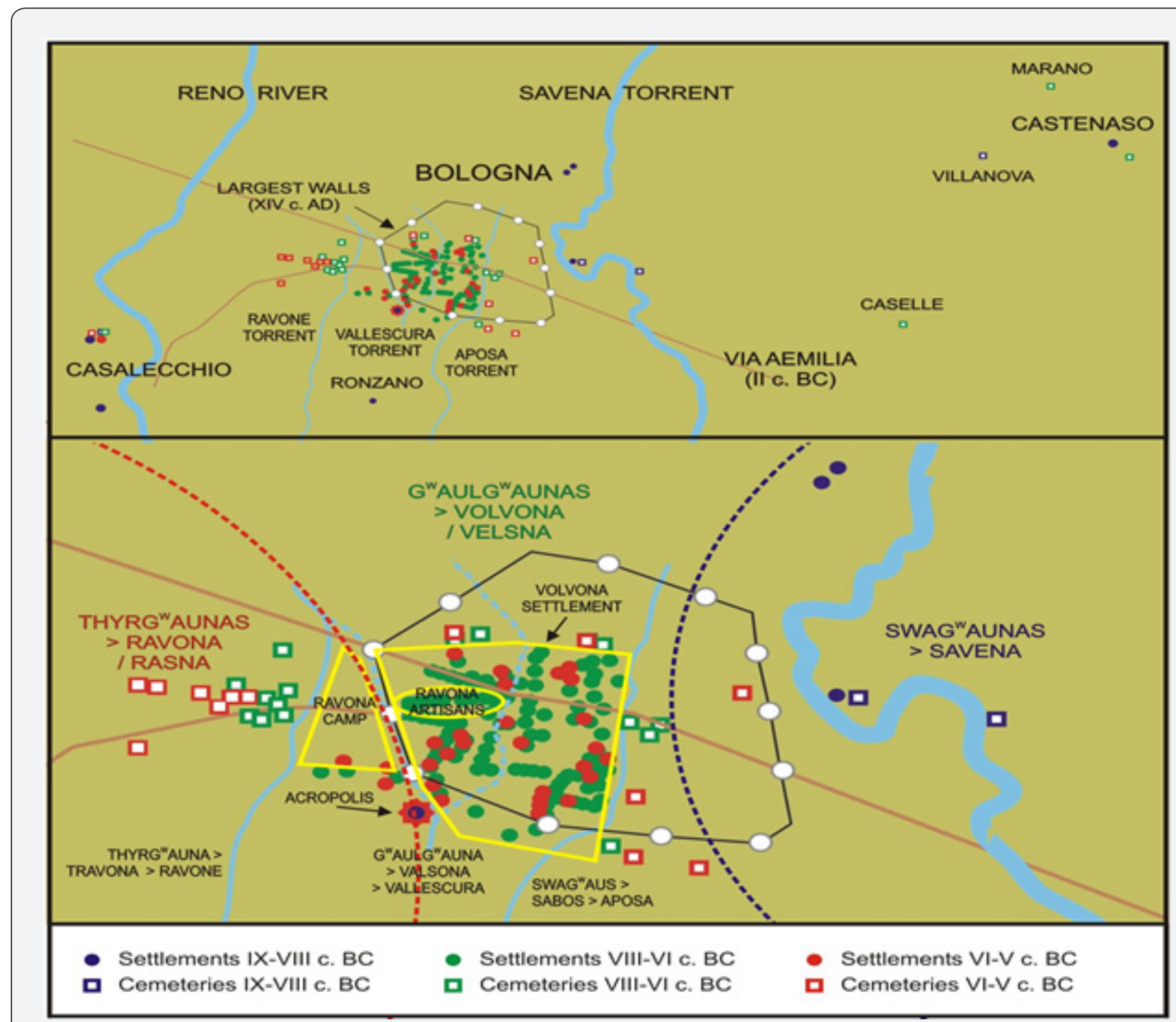

Figure 1: Settlements and cemeteries dating back to the Etruscan age in Bologna and around.

\section{Conclusion}

After having considered the earl archaeological finds discovered in Bologna and in the surrounding area, and the peoples that inhabitated Italy at the corresponding times and some centuries before, we come to the following conclusions.
In the middle of the II millennium $\mathrm{BC}$, the lands around Bologna were mainly inhabitated by $G^{w}$ aumbras and *Swagwaunas. The latter lived on cattle breeding, the former also on agriculture, craft and trading. $G^{w}$ aumbras had arrived in Italy as the first from Central-Eastern Europe (Únětice culture). Shortly later ${ }^{*}$ Swag ${ }^{w}$ aunas had occupied the Padanian Valley 
with their large herds of cows, chasing $G^{w}$ aumbras on the hills of the Apennine chain from Liguria to Marches.

Toward the end of the II millennium BC, new tribes of *Swagwaunas $\quad\left({ }^{*} S g^{w}\right.$ ytulas $/{ }^{*} S g^{w}$ etulas $), \quad$ Proto-Gaul-Latins ( ${ }^{*} G^{w}$ aulatanas), and the Mixed People arrived in Italy. The first peoples just crossed the Padanian Valley, descending on Tuscany and diffusing along the Tyrrhenic coast, pressed by the Mixed People. The newcomers also forced a part of previous *Swag ${ }^{w}$ aunas to cross the Apennine and settle in Tuscany and later in Lazio, and $G^{w}$ aumbras to move eastward in the Apennine and to Romagna. Inside the Mixed People, ${ }^{*} G^{w}$ aulgwaunas occupied the grasslands in the Padanian Valley and along the Tirrhenic coast and ${ }^{*}$ Thyrg $^{w}$ aunas headed to the commercial ports.

In the Villanovian age $G^{w}$ aumbras who previously had descended from the hills to the grasslands of Romagna breeding cattle, started concentrating in the hinterland of Rimini, while *Swag ${ }^{w}$ aunas who remained in the Padanian Valley concentrated in proximity of Bologna. They were nomads, probably moving through the grasslands on charriots and living in tents. In the Villanovian age they assumed an organisation with a central controll which required stable structures, similar to tents but with fixed larger poles more deeply driven into the groung. We can then observe in Bologna the holes of the poles of such structures. They were mostly located by a torrent, the Savena, which took names after *Swag ${ }^{w}$ aunas. Near this structures were cemeteries. Probably, the most of the population still was nomad, living in structures which left no trace.

In the formative phase, the descendants of ${ }^{*} G^{w}$ aulgwaunas, the Volvona, started concentrating in Bologna and in the protourban phase took the control over the territory. The descendants of *Swagwaunas, called Sàvena by Volvona, still lived in the area between Aposa and Savena torrents and further east, but the administrative structures were moved into the new city sector founded by Volvona. These were confederates of the descendants

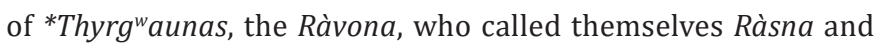
had their villages along the commercial routes. Near Bologna, in particular, Ravona had settled in current Casalecchio by a river, the Reno, which took name after them. From Casalecchio, Ravona had the controll over the commerce between the Padanian Valley and Etruria through the Reno and Ombrone valleys. They also had commercial exchanges with Volvona in Bologna, whom they called Vèlsna or Vèlzna.

Probably, Ravonian merchants frequently visited the city of Volvona and lived in the closest part of the city, the western one, by the Ravone torrent, to which they left their name. They come with their charriots, put up their tents, and exopsed their merchandise, remaining the period necessary to sell all their own goods and to buy wares from Volvona and other peoples visiting the city. It is also likely that in the course of the time some Ravonian artisans also settled beyond the western branch of Vallescura torrent around a street which now is called "Via del
Pratello" and previously "Peradello". This name may be derived from *Perdela $<{ }^{*}$ Pherdaila $<{ }^{*}$ Thyrg ${ }^{w}$ aula as well as other similar toponyms such as Piratello near Imola or Fiesole (Etr. Vipsul, with a Greek rho, Visul, and Viesl < *Phirzola < *Phyrdaula < ${ }^{*}$ Thyrgw ${ }^{w}$ aula) near Florence. For their activities, among which metal processing, such artisans required stabled structures which left traces in the ground. Ravonian merchants and artisans habitually visiting or settled by Volvona had their cemeteries beyond Ravone torrent.

In VI-V century BC Greeks took the control over Tyrrhenic Sea, forcing Etruscans to trade through the ports in Adriatic Sea and the routes toward the North. This caused an enhancement of the commerce between Etruria and Padanian Valley through the Tuscan-Emilian Apennine valleys and the plains further north and east. Ravona, who controlled some centers along the commercial routes, required the cooperation of Volvona, who uccupied the sourrounding countryside. Such a cooperation was particularly necessary in Bologna, whence the main routes to the Adriatic ports and to the North departed and Volvona controlled the Savena valley. Therefore, in the late-urban phase of the city the ancient route connecting Casalecchio was paved and Ravona partecipated to the restructuration of the city by erecting with their techniques new buildings for rite and sacrality in an high ground zona in the middle between Aposa torrent, the eastern limit of the previous Volvonian residential area, and Ravone torrent, the western limit of the previous Ravonian commercial area. Such kind of cooperation reflected in a restructuration of the city can be observed in other urban centers interessed by the enhanced trading between Etruria and Padanian Valley as, for example, Kainua (Marzabotto) in the Reno valley [38].

\section{References}

1. Banti L (1969) Il mondo degli Etruschi. Biblioteca di Storia Patria, Roma, Italy pp. 129.

2. Fabbri G (2017) Supartshas and Swagwautas - colonisers of the ancient word. Part I: Origins and early migrations. Journal of Ancient History and Archaeology 4(4): 5-27.

3. Fabbri G. (2018) Supartshas and Swag'wautas - colonisers of the ancient word. Part II: late migrations. Journal of Ancient History and Archaeology 5(1): 5-23.

4. Pallottino M (2016) L'Etruscologia. Hoepli, Milan, Italy, p. 452.

5. Herodotus ( $440 \mathrm{BC}$ ) Histories $4: 6$.

6. Herodotus (440 BC) Histories 1: 201-216.

7. Szemerényi O (1980) Four old iranian ethnic names: Scythian - Skudra - Sogdian - Saka. Verlag der Österreichischen Akademie der Wissenschaften, Vienna, Austria p. 7.

8. Anonymous (VI-V c. BC) Genesis. Bible. 10: 3.

9. Jeremiah (586 BC) Book of Jeremiah. Bible 51: 27.

10. Gimbutas M (2017) I Balti. Medusa, Milano, Italy p. 56.

11. Plutarchus LM (I-II c.) Vita Marii. Vitae Parallelae 19: 3-4.

12. Pallottino M. (2016) L’Etruscologia. Hoepli, Milan, Italy pp. 240.

13. Plinius GS (77) Naturalis Historia. 3: 115. 
14. Livius T (14) Ab Urbe Condita, XXXI, 2 and XXXIII, 37.

15. Herodotus (440 BC) Histories p. 9.

16. Strabo (23) Geography VII. 3: 2

17. Herodotus (440 BC) Histories, VII, 20.

18. Strabo (23) Geography, VIII, 6: 19.

19. Pallottino M (2016) L’Etruscologia. Hoepli, Milan, Italy pp. 6.

20. Pallottino M (2016) L'Etruscologia. Hoepli, Milan, Italy pp. 131.

21. Banti L (1969) Il mondo degli Etruschi. Biblioteca di Storia Patria, Roma, Italy pp. 163.

22. Ortalli J (2016) Altre noterelle su Felsina (risposta a Giuseppe Sassatelli). Thiasos 5(5), 17-32.

23. Fanti M (2000) Le Vie di Bologna. Istituto per la Storia di Bologna, Bologna, Italy, 2000. II: 787.

24. Fanti M (2000) Le Vie di Bologna. Istituto per la Storia di Bologna, Bologna, Italy, 2000. I, 178.

25. Pallottino M (2016) L'Etruscologia. Hoepli, Milan, Italy pp. 271.

26. Dionysius H (I c.) Roman Antiquities, I, 30, 3.

27. Pallottino M (2016) L'Etruscologia. Hoepli, Milan, Italy pp. 128.

28. Pittau M (2018) Dizionario comparativo Latino Etrusco. Ipazia Books, Dublin, Ireland: 261.
29. Pallottino M (2016) L’Etruscologia. Hoepli, Milan, Italy pp. 208

30. Sassatelli G (2009) Riflessioni sulla stele della nave di Bologna. Etruria e Italia preromana. Studi in onore di Giovannangelo Camporeale. Bruni S (Eds.), Pisa-Roma, Italy pp. 833-840.

31. Sassatelli G, Morigi C (1966) Felsina etrusca. Storia di Bologna. Grafis, Bologna, Italy p. 11-28.

32. Pallottino M (2016) L’Etruscologia. Hoepli, Milan, Italy: 151.

33. Manfroni G (2005) Il ripostiglio di San Francesco di Bologna: studio dei frammenti di cinturoni villanoviani. Archeologia Classica 56: 419-451.

34. Sassatelli G (1990) La situazione in Etruria Padana. Crise et transformation des sociétés archaïques de l'Italie antique au Ve siècle av. JC. Actes de la table ronde de Rome. École Française de Rome, Rome, Italy pp. 51-100.

35. Sassatelli G (2010) Bologna etrusca e la sua espansione nel territorio tra Reno e Panaro. Cavalieri etruschi dalle Valli al Po. Tra Reno e Panaro, la Valle del Samoggia nell'VIII e VII secolo a.C.. Burgio, Campagnari, Malnati editors, Aspasia, Bologna, Italy: 27-35.

36. Poli P, Sindaco M (2016) All'oriente di Bologna. Archeo 373: 60-67.

37. http://www.grafaz.it/Portals/0/doc/MeridianaNelTempo/MappaArcheologicaMeridiana001.jpg

38. Fabbri G (2017) Kainua Misena e il popolo misto degli Etruschi. Scienze e Ricerche 51: 41-51.

\section{Your next submission with Juniper Publishers will reach you the below assets}

- Quality Editorial service

- Swift Peer Review

- Reprints availability

- E-prints Service

- Manuscript Podcast for convenient understanding

- Global attainment for your research

- Manuscript accessibility in different formats

( Pdf, E-pub, Full Text, Audio)

- Unceasing customer service

Track the below URL for one-step submission

https://juniperpublishers.com/online-submission.php 